\title{
Placentation in mammals once grouped as insectivores
}

\author{
ANTHONY M. CARTER ${ }^{*}, 1$ and ALLEN C. ENDERS ${ }^{2}$ \\ ${ }^{1}$ Department of Physiology and Pharmacology, University of Southern Denmark, Odense, Denmark and \\ ${ }^{2}$ Department of Cell Biology and Human Anatomy, University of California, Davis, CA, USA
}

\begin{abstract}
Interest in insectivoran grade mammals has been reawakened by taxonomic changes that place tenrecs and golden moles in a new order and separate hedgehogs from moles, shrews and solenodons. This survey of their placentation shows there is great variation even within families. As an example three subfamilies of tenrec have been examined. The interhemal region is cellular hemomonochorial in Echinops and Microgale but endotheliochorial in Micropotamogale. Golden moles, which are placed in the same order, have hemodichorial placentation. Many insectivores have complex arrangements for histotrophic nutrition involving columnar trophoblast cells. These range from areolae in moles through complexly folded hemophagous regions in tenrecs to the trophoblastic annulus in shrews. Of these placental characters, few offer support to current phylogenies. However, the case for placing hedgehogs and gymnures in a separate order (Erinaceomorpha) is bolstered by the presence of interstitial implantation, amniogenesis by cavitation, a hemochorial barrier and a prominent spongy zone; these features do not occur in shrews, moles or solenodons (Soricomorpha). Three insectivoran grade mammals deserve close attention as they have been selected for genome sequencing. One of these, the European hedgehog (Erinaceus europaeus), has not been studied with current methodology and renewed investigation of this or the closely related genus Atelerix should be a priority.
\end{abstract}

KEY WORDS: fetal membrane, golden mole, hedgehog, mole, phylogeny, placenta, shrew, solenodon, tenrec

\section{Introduction}

Mammals appear in the fossil record at around the same time as dinosaurs (Kielan-Jaworowska et al., 2004) and the earliest fossils of marsupial and placental mammals date from the Early Cretaceous of China (Ji et al., 2002; Luo et al., 2003). Early mammals were tiny creatures and their teeth, often all that remains, indicate an insectivorous diet. These traits are shared by a number of living mammals that accordingly were lumped together in a single order. After some initial pruning this order was given the name Lipotyphla (Simpson, 1945). It was early recognized that these insectivores had many "primitive" characters. Hubrecht (1889) chose them deliberately as the mammals most likely to preserve primitive characters of placentation. His lead was followed by other embryologists (Fig. 1). Later attention waned with relatively few studies of insectivore placentation appearing in the last half of the twentieth century.

Interest in insectivoran grade mammals has been rekindled because of the findings of molecular phylogenetics. These necessitated a complete reorganization of the group once it was recognized that the golden moles and the Malagasy tenrecs belonged to a separate lineage (Stanhope et al., 1998). They were placed in their own order Afrosoricida as part of Afrotheria (Fig. 2). Afrotheria is one of four superordinal clades of mammals and includes elephants, sea cows, hyraxes, aardvarks and elephant shrews. Because these relationships had never before been suggested, it stimulated a search for morphological characters that might support such a diverse assemblage (Seiffert, 2007), including our own studies of placentation in tenrecs.

The other insectivores remained in a truncated order that was seen to belong to another superordinal clade, Laurasiatheria (Murphy et al., 2001). However, the molecular data soon confirmed, as long had been suspected, that this was a heterogeneous assemblage. The most recent review of mammalian taxonomy (Fig. 2) separates out the hedgehogs and their allies in Erinaceomorpha and puts shrews, moles and solenodons in Soricomorpha. (Hutterer, 2005 a,b)

A review of placentation in insectivoran grade mammals is long

Abbreviations used in this paper: PAS, periodic acid Schiff reaction; TEM, transmission electron microscopy.

\footnotetext{
*Address correspondence to: Anthony M. Carter. Physiology and Pharmacology, University of Southern Denmark, DK-5000, Odense, Denmark. e-mail: acarter@health.sdu.dk
} 
overdue and will complement other reviews of the reproductive biology of these creatures (Bedford et al., 2004; Symonds, 2005). We here summarize our studies of tenrecs and golden moles and review what is known about the other families. The emphasis is on the definitive placenta including the interhemal barrier and some fascinating arrangements for hemotrophic nutrition. Details of earlier development are given where appropriate and summarized in synoptic Tables. In the course of this project we examined Hubrecht's original material on the European hedgehog and common shrew as well as Mossman's collection of American shrews and moles.

As they did a century ago several of these species figure prominently in current attempts to further our understanding of genetics and phylogeny through comparative genomics (Springer and Murphy, 2007). Three insectivores are among the 16 mammals sequenced as part of the Mammalian Genome Project: the lesser hedgehog tenrec (Echinops telfair), common shrew (Sorex araneus) and European hedgehog (Erinaceus europaeus). The full exploitation of such powerful data bases presupposes that we have a full understanding of the corresponding phenotypes including their anatomy, physiology and immunology. For that reason our aim has been not only to summarize what we know about placentation in insectivores but to highlight what still needs to be done.

\section{Early development}

Events leading to establishment of the placenta are summarized in Tables 1 and 2. Implantation is superficial in most families but secondarily interstitial in the hedgehog Erinaceus europaeus (Hubrecht, 1889) and the moonrat Echinosorex gymnura(Hubrecht 1898). In the crocidurine shrews, exemplified by Suncus murinus, implantation occurs within a pocket of endometrium or implantation chamber (Sansom, 1937). The lips of the chamber then close over to form a decidua capsularis. This is perforated later in development and becomes an annular fold. Vestiges of the decidua capsularis have been identified in soricine shrews (Brambell and Perry, 1945). Implantation has not been observed

TABLE 1

\section{FETAL MEMBRANES AND PLACENTATION OF INSECTIVORAN GRADE MAMMALS CURRENTLY ASSIGNED TO ORDERS ERINACEOMORPHA AND SORICOMORPHA ${ }^{1}$}

\begin{tabular}{|c|c|c|c|c|c|}
\hline Family (subfamily) & Erinaceidae & Soricidae (Soricinae) & Soricidae: (Crocidurinae) & Talpidae & Solenodon-tidae \\
\hline Species & Erinaceus europaeus & Sorex araneus & Suncus murinus & Talpa europaea & Solenodon paradoxus \\
\hline Implantation & Interstitial & Superficial & $\begin{array}{l}\text { Superficial but with decidua } \\
\text { capsularis }\end{array}$ & Superficial & $\begin{array}{l}\text { Unknown but with decidua } \\
\text { capsularis }\end{array}$ \\
\hline Amniogenesis & Cavitation & Folding & Folding & Folding & Unknown \\
\hline Bilaminar omphalopleure & Persists to term & Persists to term & Persists to term & Persists to term & Small fragment persists to term \\
\hline Choriovitelline placenta & Temporary & Temporary & Temporary & Temporary & Temporary \\
\hline Visceral yolk sac & $\begin{array}{l}\text { Permanent; incomplete } \\
\text { inversion }\end{array}$ & $\begin{array}{l}\text { Permanent; incomplete } \\
\text { inversion }\end{array}$ & Permanent; incomplete inversion & $\begin{array}{l}\text { Permanent; incomplete } \\
\text { inversion }\end{array}$ & Permanent; complete inversion \\
\hline Trophoblastic annulus and curtain & Absent & Present & Present & Absent & Absent \\
\hline Allantoic sac & Medium & Stalk only & Stalk only & Medium to large & Stalk only \\
\hline Placental shape & Discoid & Discoid & Discoid & Discoid or zonary & Discoid \\
\hline Pattern & Labyrinthine & Labyrinthine & Labyrinthine & Labyrinthine or villous & Labyrinthine \\
\hline Interhemal membrane & Hemo-chorial & Endothelio-chorial & Endothelio-chorial & Endothelio-chorial & Hemo-chorial \\
\hline Trophospongium & Present & Absent & Absent & Absent & Absent \\
\hline Trophoblastic sheath & Absent & Absent & Present & Absent & Present \\
\hline Areolae & Absent & Absent & Absent & Present & Absent \\
\hline
\end{tabular}

${ }^{1}$ Some authorities place these families in a single order Eulipotyphla

TABLE 2

FETAL MEMBRANES AND PLACENTATION OF INSECTIVORAN GRADE MAMMALS CURRENTLY ASSIGNED TO ORDER AFROSORICIDA

\begin{tabular}{|c|c|c|c|c|}
\hline Family (subfamily) & Tenrecidae (Tenrecinae) & Tenrecidae (Oryzorictinae) & Tenrecidae (Potamogalinae) & Chrysochloridae \\
\hline Species & Echinops telfairi & Microgale spp. & Micropotamogale lammottei & Amblysomus hottentotus \\
\hline Implantation & Superficial & Superficial & Superficial & Superficial \\
\hline Amniogenesis & Cavitation & Not known & Not known & Folding \\
\hline Bilaminar omphalopleure & Blastocyst only & Temporary & Not known & Blastocyst only \\
\hline Choriovitelline placenta & Temporary & Temporary & Temporary & Temporary \\
\hline Visceral yolk sac & Permanent; incomplete inversion & Permanent; incomplete inversion & Permanent; incomplete inversion & Permanent; incomplete inversion \\
\hline Allantoic sac & Large & Large & Large & Medium \\
\hline Placental shape & Discoid & Discoid & Discoid & Discoid \\
\hline Pattern & Labyrinthine & Villous early but labyrinthine later & Labyrinthine & Labyrinthine \\
\hline Interhemal membrane & Hemochorial & Hemochorial & Endothelio-chorial & Hemochorial \\
\hline Trophospongium & Present & Absent & Absent & Present \\
\hline Areolae & Present in Tenrec ecaudatus & Absent & Absent & Absent \\
\hline Hemophagous region & Folded, saccular central structure & Unfolded part of paraplacenta & Folded, saccular central structure & Absent \\
\hline
\end{tabular}


in Solenodon but the mid-gestation placenta is flanked by what Wislocki (1940) interpreted as the remains of a decidua capsularis.

In all these families a choriovitelline placenta is formed initially, but the yolk sac is displaced from the trophoblast adjacent to the uterine wall upon expansion of the exocelom and allantois. A partially inverted yolk sac remains to term. In the golden mole Eremitalpa granti it has been thought that a choriovitelline placenta is retained throughout gestation (Mossman, 1987) but this is not the case in Amblysomus hottentotus (Jones et al., 2009).

\section{Chorioallantoic placenta}

In most insectivores the definitive placenta is sharply circumscribed and roughly discoidal in shape. The overall structure of the exchange area is labyrinthine. This pattern is broken in one subfamily of moles (Scalopinae) where the placenta of several genera is more zonary than discoidal and perhaps villous, as first described for the Eastern mole Scalopus aquaticus (Mossman, 1939). Some tenrecs have quite an extensive paraplacenta. In Potamogale veloxthis is probably important in gaseous exchange since the disc functions largely as a hemophagous organ (Carter et al., 2006). There is a medium to large allantoic sac in hedgehogs, moles, tenrecs and golden moles. However, the allantoic cavity is absent in shrews and in Solenodon paradoxus; it is replaced by an allantoic stalk as in higher primates.

As shown below most insectivoran grade mammals have endotheliochorial or hemochorial placentas. In addition to exchange across the interhemal barrier, the fetus may acquire nutrients by taking up uterine gland secretions, tissue debris or maternal blood. This is referred to as histotrophic nutrition. Several insectivore placentas have prominent structures devoted to this purpose. They all are based on a type of columnar trophoblast that has a widespread distribution among mammals (Enders and Carter, 2006). This trophoblast is highly polarized and has the necessary cellular apparatus for endocytosis and lysis of nutrients.

\section{Placentation in shrews}

The three subfamilies of shrew are Crocidurinae, Myosoricinae and Soricinae (Hutterer 2005b). Placentation in crocidurine shrews is best known from Suncus murinus. Crocidura is the most
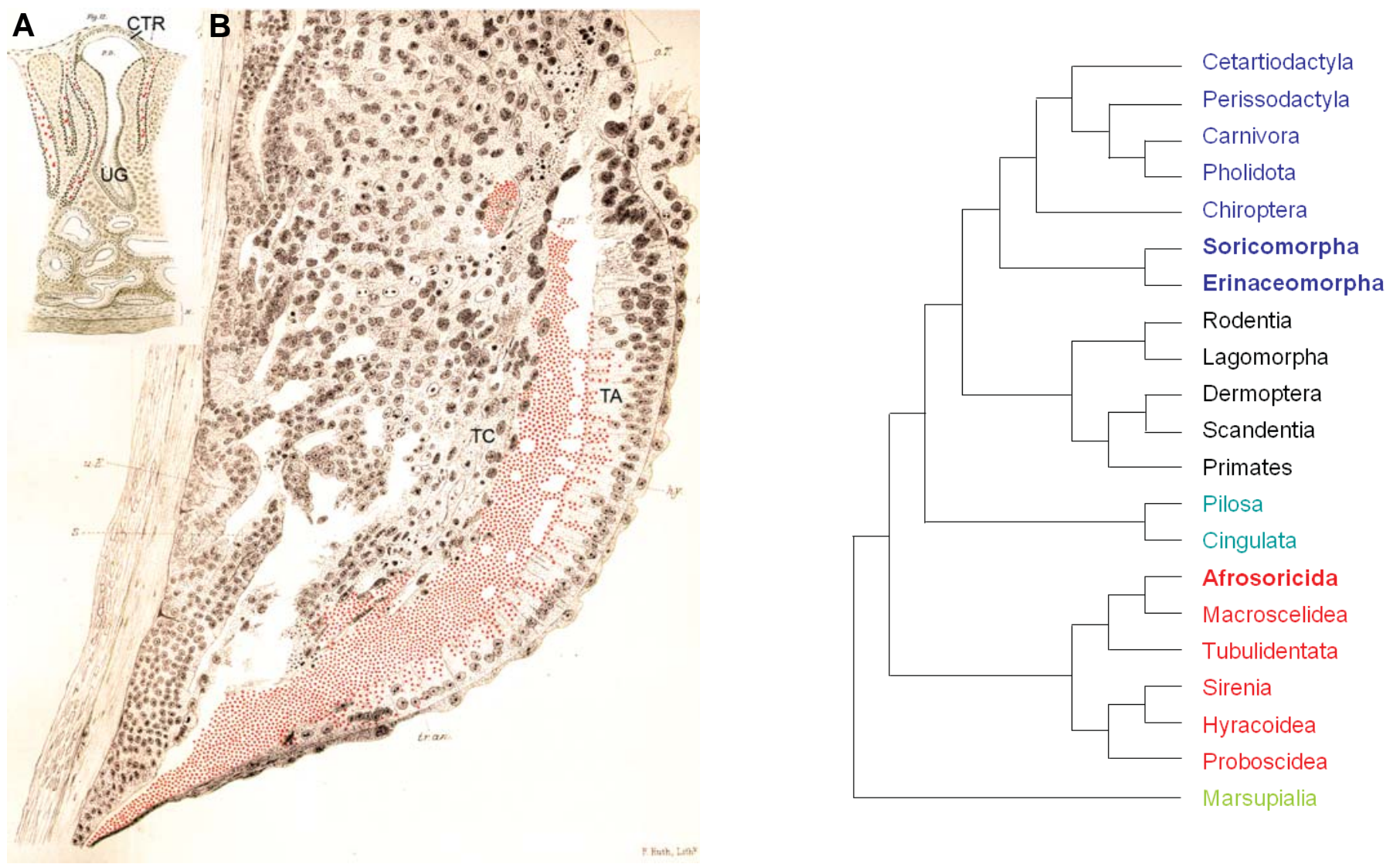

Fig. 1 (Left). Pioneering research on insectivore placentation. (A) An areola from the placenta of the European mole (Talpa europaea). The uterine gland (UG) is capped by columnar trophoblast (CTR). From Strahl (1892). (B) The trophoblastic curtain (TC) and trophoblasic annulus (TA) of the common shrew (Sorex araneus). Erythrocyte ingestion by the columnar trophoblast of the annulus is clearly seen. From Hubrecht (1894).

Fig. 2 (Right). Phylogeny of placental mammals. The twenty extant orders fall into four superordinal clades named Laurasiatheria (blue), Euarchontoglires (black), Xenarthra (sky blue) and Afrotheria (red). This tree is based on an analysis of nucleotide sequences using marsupials (lime green) as an outgroup to root the tree (Murphy et al., 2001). Insectivores are in bold type. Until quite recently the tenrecs and golden moles (Afrosoricida) were placed in the same order as hedgehogs and gymnures (Erinaceomorpha) with shrews, moles and solenodons (Soricomorpha). 
speciose genus of all mammals yet only summary accounts of its placenta are available (Starck, 1959). Nothing is known of the placenta in Myosoricinae. There are extensive studies of the soricine genera Sorex, Suncus and Blarina.

\section{Interhemal barrier}

In shrews, the interhemal barrier of the labyrinth has been the object of much confusion and controversy. The tissue surrounding the maternal blood spaces is a modified endothelium (Wimsatt and Wislocki, 1947), but was mistaken for syncytial trophoblast by earlier authors (Hubrecht, 1894; Sansom, 1937; Brambell and Perry, 1945). However the placenta is endotheliochorial rather than hemochorial. Owers (1960) went further and stated that the trophoblast was lost early in gestation and did not form part of the interhemal membrane in Suncus murinus. He proposed the term endothelio-endothelial to describe this condition. The controversy was resolved when Wimsatt et al. (1973) examined the placentas of Blarina brevicauda and Sorex cinereus by TEM (Fig. 3). They found that there is a continuous syncytial lamina. However, it has a unique organization, being honeycombed with interstitial spaces that open freely on both surfaces, giving the whole a sieve-like appearance. The cytoplasm is spread so thin that in places there is no room for granular endoplasmic reticulum or other organelles. It does appear as a continuous layer in semi-thin sections, but cannot so be distinguished in paraffin sections. In addition to the modified maternal epithelium and extraordinary trophoblast layer, the interhemal region of shrews features fetal endothelium without a basement membrane, but with unusual basal processes, and fetal mesenchymal cells that have hypertrophied and undergone epithelioid differentiation (Wimsatt et al., 1973). Kiso et al. (1990) re-examined the interhemal barrier

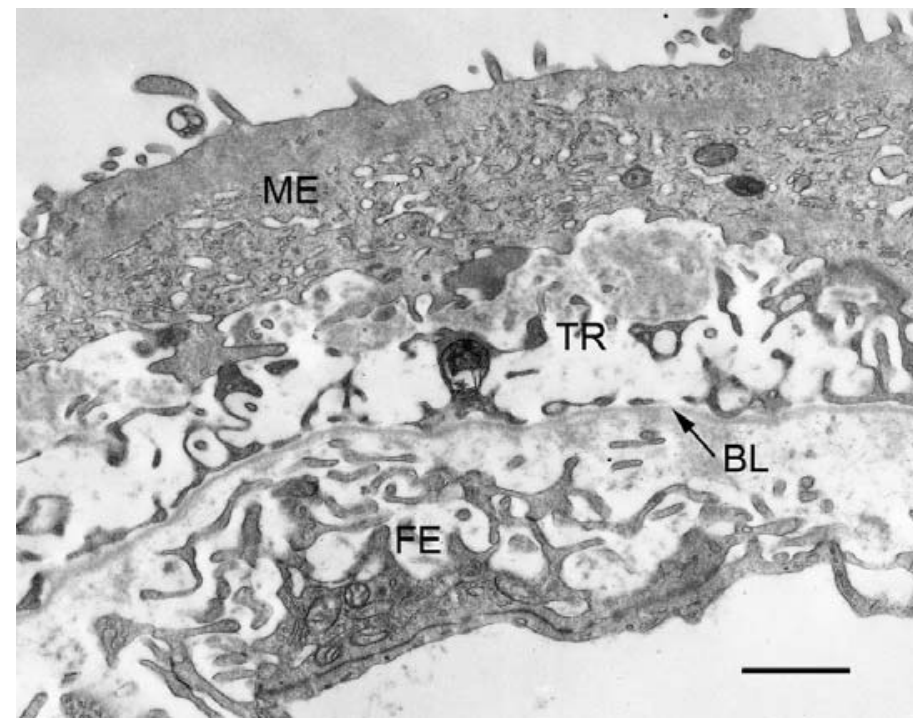

Fig. 3. Interhemal region of the endotheliochorial placenta of the Northern short-tailed shrew (Blarina brevicauda). The maternal endothelial cells (ME) display microvilli on the luminal surface. The basal lamina beneath them is broad and irregular. The trophoblast layer (TR) is attenuated due to apical and basal invaginations but has a continuous basal lamina (BL). There are irregular projections from the fetal endothelial cells (FE). Scale bar $1.1 \mu \mathrm{m}$. in dated pregnancies of $\mathcal{S}$. murinus. They found the structure described by Wimsatt et al. (1973) up to day 24 of gestation, but in the last week of gestation the syncytiotrophoblast became discontinuous.

\section{Histotrophic nutrition}

A quite unique arrangement for histotrophic nutrition is found in shrews. Cell debris and maternal erythrocytes are found in the space between the trophoblastic curtain and annulus (Fig. $1 B, 4 A-B)$. This material is released by the actions of the trophoblast of the curtain and taken up by the trophoblast of the annulus. Erythrocytes in various stages of degeneration can be demonstrated in the columnar trophoblast cells (Fig. 4C; King et al., 1978). The breakdown products apparently cross Reichert's membrane and the endoderm lining the annulus. They are then taken up by the endoderm of the visceral yolk sac. These cells contain pigment granules that are responsible for the characteristic green appearance of the fetal membranes in shrews. It has been shown that most of the pigment is bilirubin, an iron-free breakdown product of hemoglobin (Wislocki and Wimsatt, 1947). The granules stain for iron, too, indicating that hemosiderin is present (Wislocki and Wimsatt, 1947). In addition, the presence of glycogen has been demonstrated cytochemically and by TEM (Wislocki and Wimsatt, 1947; King et al., 1978). No doubt these materials are acquired by endocytosis, since the cytoplasm beneath the apical membrane contains caveolae and a variety of vesicles and tubules. The connective tissue compartment of the visceral yolk sac contains the vitelline blood vessels and hematopoietic foci. Thus acquirement of iron by endocytosis of maternal erythrocytes is spatially linked to fetal hematopoiesis. Unusually for mammals, in Suncus murinus yolk sac hematopoiesis continues to term (Sansom, 1937).

\section{Trophoblastic sheath}

A conspicuous feature of the crociduran placenta is the "trophoblastic sheath" that invests the allantoic vessels at the site of their attachment to the placenta. Described by Sansom (1937) for $S$. murinus, it clearly can be seen in Crocidura russula (Starck, 1959; Fig. 5A). The two umbilical arteries unite to form a single vessel that passes directly through the sheath. However, blood returns to the umbilical vein by way of numerous vessels that ramify in the meshwork of the trophoblastic sheath. The source of the trophoblast forming the sheath is open to discussion. Wimsatt and Wislocki (1947) make a compelling case for homology between the trophoblastic sheath of Crocidurinae and nests of cytotrophoblast found at the base of the allantoic villi in Soricinae. They argue that Sansom (1937) failed to provide direct evidence for his assumption that the sheath was derived from binucleate trophoblast cells. A third interpretation was offered by Owers (1960) who believed that the structure was derived from proliferating uterine epithelium.

\section{Placentation in solenodons}

Solenodons are a relict confined to the Greater Antilles. Both extant species are endangered and we are fortunate in having a description of the definitive placenta by Wislocki (1940). He found that Solenodon paradoxus has a typical hemochorial 

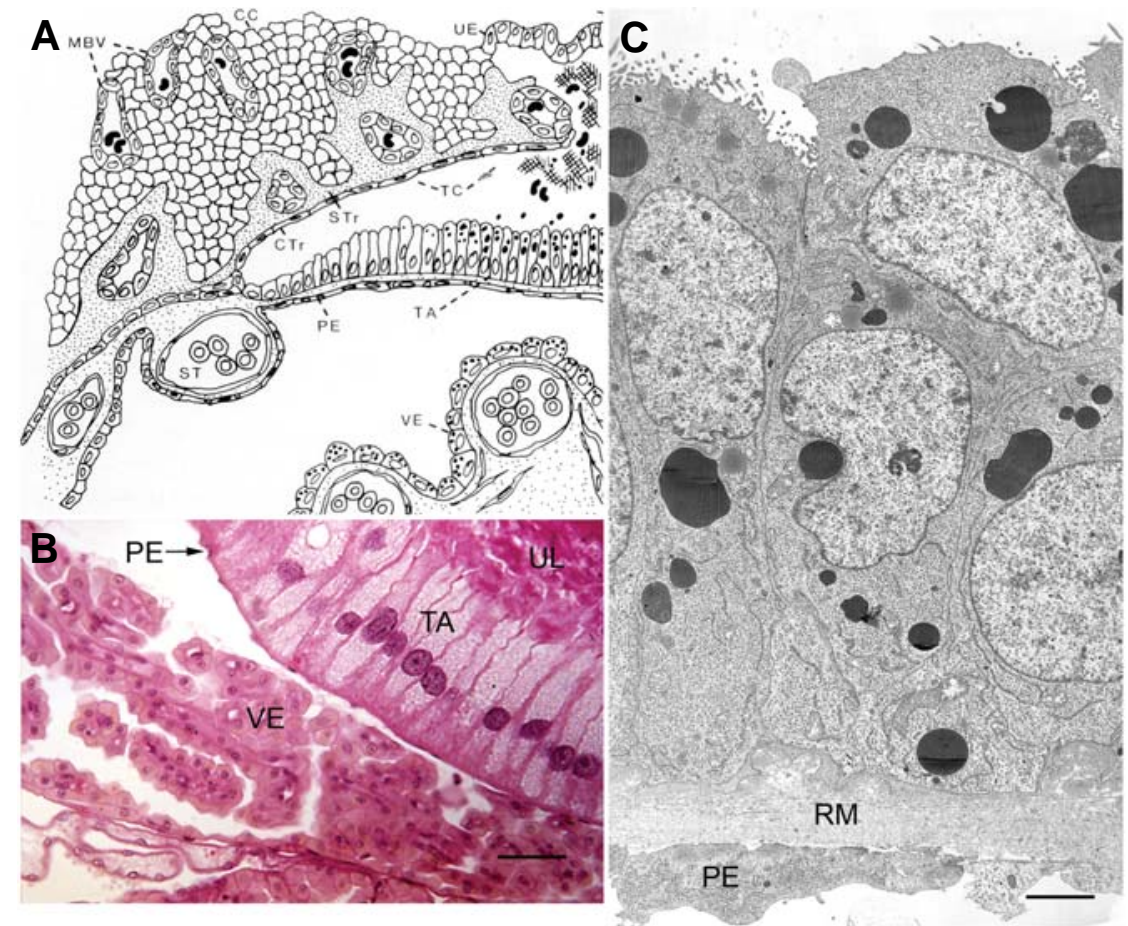

Fig. 4. Histiotrophic nutrition in the placenta of a shrew (B. brevicauda). (A) Diagram showing the relation between the uterine trophoblastic curtain (TC) and the trophoblastic annulus of the yolk sac. Syncytiotrophoblast (S Tr) surrounds maternal capillaries (MBV) and has an outer covering of cytotrophoblast (C Tr). In places this is lost and masses of syncytium, cellular debris and maternal erythrocytes are sloughed off into the lumen. This material is phagocytosed by the tall columnar cells of the trophoblastic annulus (TA). This columnar trophoblast is separated from the parietal endodermal cells (PE) by Reichert's membrane. The visceral endodermal cells (VE) border the yolk sac cavity and contain granules of green pigment. From King et al. (1978). Copyright (C) 1978. Reprinted with permission of Wiley-Liss, Inc., a subsidiary of John Wiley \& Sons, Inc. (B) Trophoblastic annulus and visceral yolk sac in Crocidura sp. UL is uterine lumen with debris; other labels as in panel (A). Courtesy of the Harland W. Mossman Collection, University of Wisconsin Zoological Museum. (C) Columnar trophoblast cells of the trophoblastic annulus in $\mathrm{B}$. brevicauda. The apical membrane facing the uterine lumen has microvilli. The lateral borders are closely apposed. Within the cytoplasm are phagocytosed erythrocytes or erythrocyte fragments. Beneath the trophoblast is Reichert's membrane (RM). Part of a parietal endodermal cell (PE) is seen. Reproduced from King et al. (1978). Copyright (C) 1978. Reprinted with permission of Wiley-Liss, Inc., a subsidiary of John Wiley \& Sons, Inc. Scale bars 37 (B), 2.85 (C) $\mu \mathrm{m}$.

labyrinth. On the fetal side there is a core of fetal capillaries and mesenchyme clothed by a delicate sheath of syncytiotrophoblast.

A trophoblastic sheath surrounds the principal allantoic vessels of Solenodon (Fig. 5B). It is made up of cords of trophoblast enclosing lacunar spaces. The apparent similarity to crociduran shrews is striking, the more so since nothing approaching these structures is known from any other mammal. According to Wislocki (1940), however, the spaces communicate with maternal blood lacunae in the labyrinth. The small amount of blood contained within them is maternal in origin and occurs together with granular debris. The fetal venous channels seen in the trophoblastic sheath of crociduran shrews are absent.

Two other interesting features in S. paradoxus (Fig. 5B) are the decidua capsularis and differentiation of the visceral yolk sac above the placenta into a series of richly branching villi that likely function to absorb histiotrophe (Wislocki, 1940). Whilst unusual among insectivores, elongated villi are seen in hystricomorph rodents such as the agouti (Dasyprocta leporina; Miglino et al., 2002).

\section{Placentation in moles}

Moles are fossorial or subfossorial mammals of which three subfamilies cur- rently are recognized (Hutterer, 2005b). Scalopinae includes three genera with a diffuse placenta and Condy/urawith a more discoid placenta (Mossman, 1989). Talpinae includes moles and desmans. Nothing is known about placentation in the Asiatic shrew moles, subfamily Uropsilinae.

\section{Interhemal barrier}

The interhemal barrier of the European mole Talpa europaea
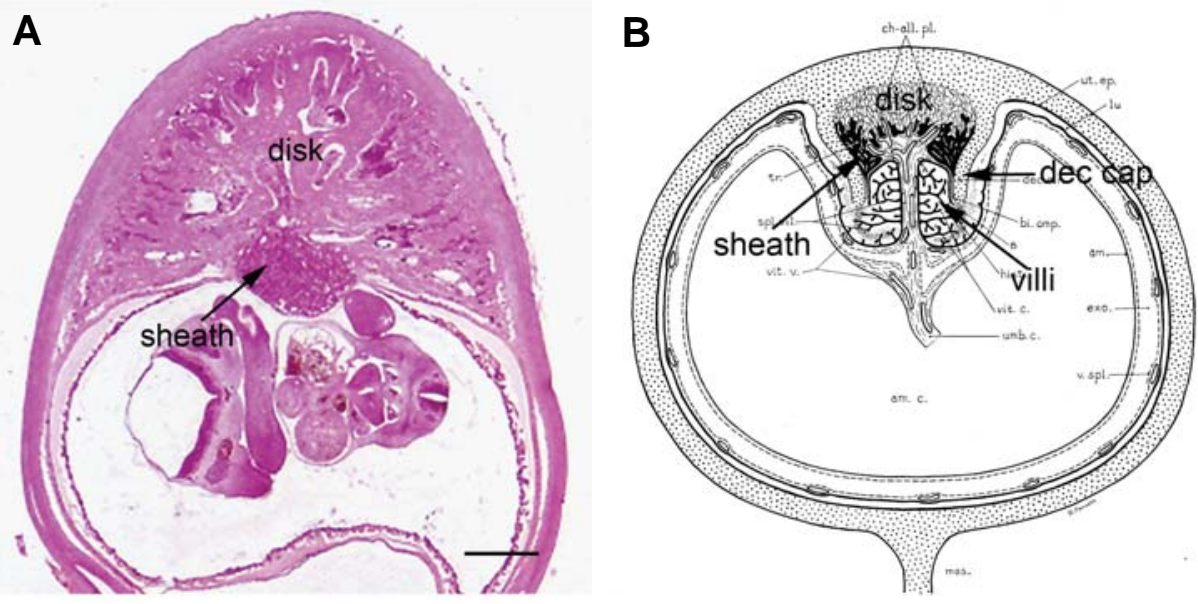

Fig. 5. The trophoblastic sheath of shrew and solenodon placentas. (A) In the Asian house shrew (Suncus murinus) the sheath is seen at the fetal surface of the placental disk. Courtesy of the Harland W. Mossman Collection, University of Wisconsin Zoological Museum. (B) In the Hispaniolan solenodon (Solenodon paradoxus) a remarkably similar sheath appears in the same position. Note also the presence of a decidua capsularis (dec cap) and the elaborately branched villi of the visceral yolk sac (villi). From Wislocki (1940). Copyright (C) 1940. Reprinted with permission of Wiley-Liss, Inc., a subsidiary of John Wiley \& Sons, Inc. Scale bar, $317 \mu \mathrm{m}$. 


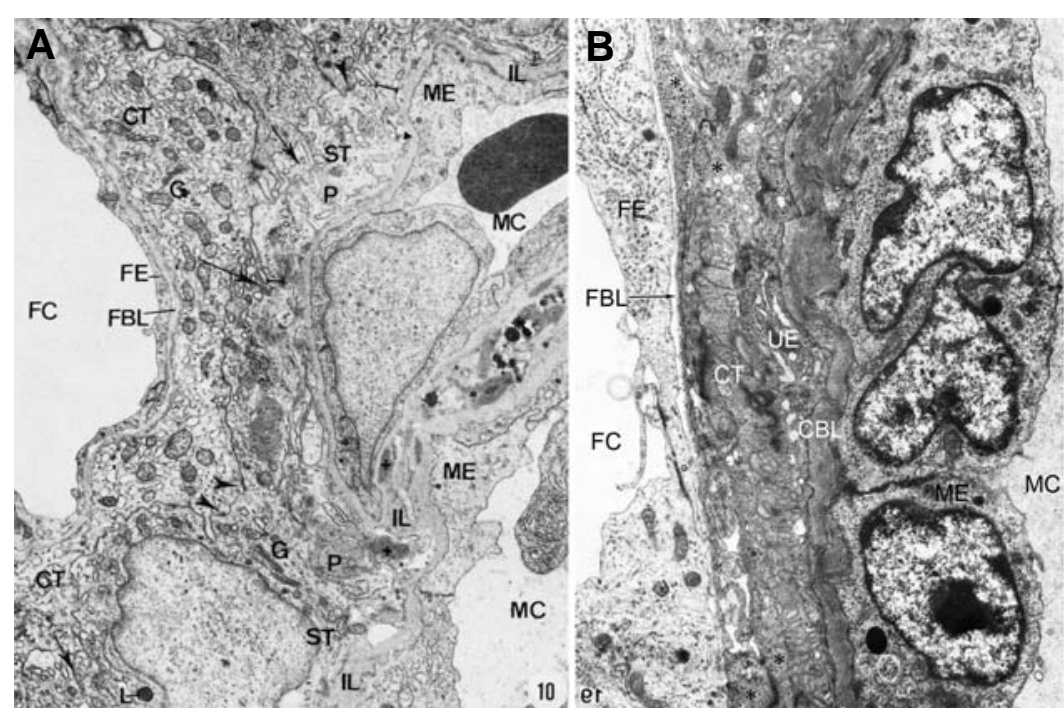

Fig. 6. The interhemal region of the placenta in moles. (A) The placenta of the European mole as interpreted by Malassiné \& Leiser is endotheliochorial. MC, maternal capillary; ME, maternal endothelium; IL, interstitial layer; ST, syncytiotrophoblast; CT, cytotrophoblast; FBL, fetal basal lamina; FE, fetal endothelium; FC, fetal capillary. From Malassiné \& Leiser (1984) copyright (C) 1984 with permission from Elsevier. (B) The placenta of the Eastern mole as interpreted by Prasad et al. is epitheliochorial. UE, uterine epithelium; CBL, complex layer composed of basal laminae of endothelium and uterine epithelium; other labels as above. Adapted from Prasad et al. (1979). Copyright (C) 1979. Reprinted with permission of Wiley-Liss, Inc., a subsidiary of John Wiley \& Sons, Inc.

is endotheliochorial (Malassiné and Leiser, 1984; Fig. 6A). As frequently is the case in placentas of this type, the maternal endothelial cells are enlarged. They rest on a thick interstitial membrane. Beneath this are two layers of trophoblast, the outer syncytial and the inner cellular, then the fetal capillary endothelium with its basal lamina. The two layers of trophoblast are connected by interdigitation of their membranes as well as by desmosomes and gap junctions.

Mossman (1939) declared that the placenta of the Eastern mole, Scalopus aquaticus, was epitheliochorial. His graduate student later found that the uterine epithelium disappeared during establishment of the yolk sac placenta, only to reappear in the chorioallantoic placenta (Prasad, 1958; see Carter, 2005). Prasad et al. (1979) established by TEM that the placenta was epitheliochorial at the single stage available for study (Fig. 6B). It will be seen that the number of layers in the interhemal membrane of Scalopus is the same as in Talpa. In both the maternal endothelium is underlain by a thick interstitial membrane. According to Prasad et al. (1979), in Scalopus this is formed by fusion of

Fig. 7. Placentation in the Southern African hedgehog (Atelerix frontalis). (A) Overview of a midgestation placenta. The arrow indicates a layer of small cells situated between the labyrinth and spongy zone. (B) Detail of the labyrinth showing maternal blood channels (MBC), fetal capillaries (FC) and trophoblast (TR). (C) The giant cell layer is interposed between the spongy zone and the unmodified connective tissue of the endometrium. Arrow as in panel (A). (D) Note that most cells in the spongy zone are vacuolated and there is a large mass of giant cells beneath them. (A-D) Courtesy of the Harland W. Mossman Collection, University of Wisconsin Zoological Museum. Scale bars 800 (A), 13 (B), $88(C)$ and 35 (D) $\mu m$. the basal laminae of the endothelium and the uterine epithelium. The layer identified as epithelium has widely scattered nuclei and the intervening regions are very thin. No cell junctions can be seen, so this layer is syncytial. Beyond it is a more substantial layer of cytotrophoblast. There is interdigitation between microvilli on the trophoblast cells and processes from the syncytial layer. Desmosomes occur at the junction between the two layers. It will be seen that the characteristics of the putative epithelial layer in Scalopus match those of the syncytiotrophoblast in Talpa. The final component of the interhemal membrane is the fetal capillary endothelium.

\section{Histotrophic nutrition}

The placental areolae of moles appear at the stage of yolk sac placentation and are retained through the chorioallantoic stage, as first described by Strahl (1892; Fig. 1A). The uterine glands persist in the region of the placenta and a dome-like structure of columnar trophoblast covers the opening of each gland. A PAS-positive substance fills the lumen of the glands and can be found within the trophoblast cells (Morris, 1958; Prasad et al., 1979). There is some extravasation of blood and erythrocytes are taken up by the trophoblast in Talpa although not in Scalopus. The glandular epithelium immediately below the areolae shows signs of differentiation, but the epithelium in the neck of the gland appears to be trophoblast-resistant (Malassiné and Leiser, 1984).

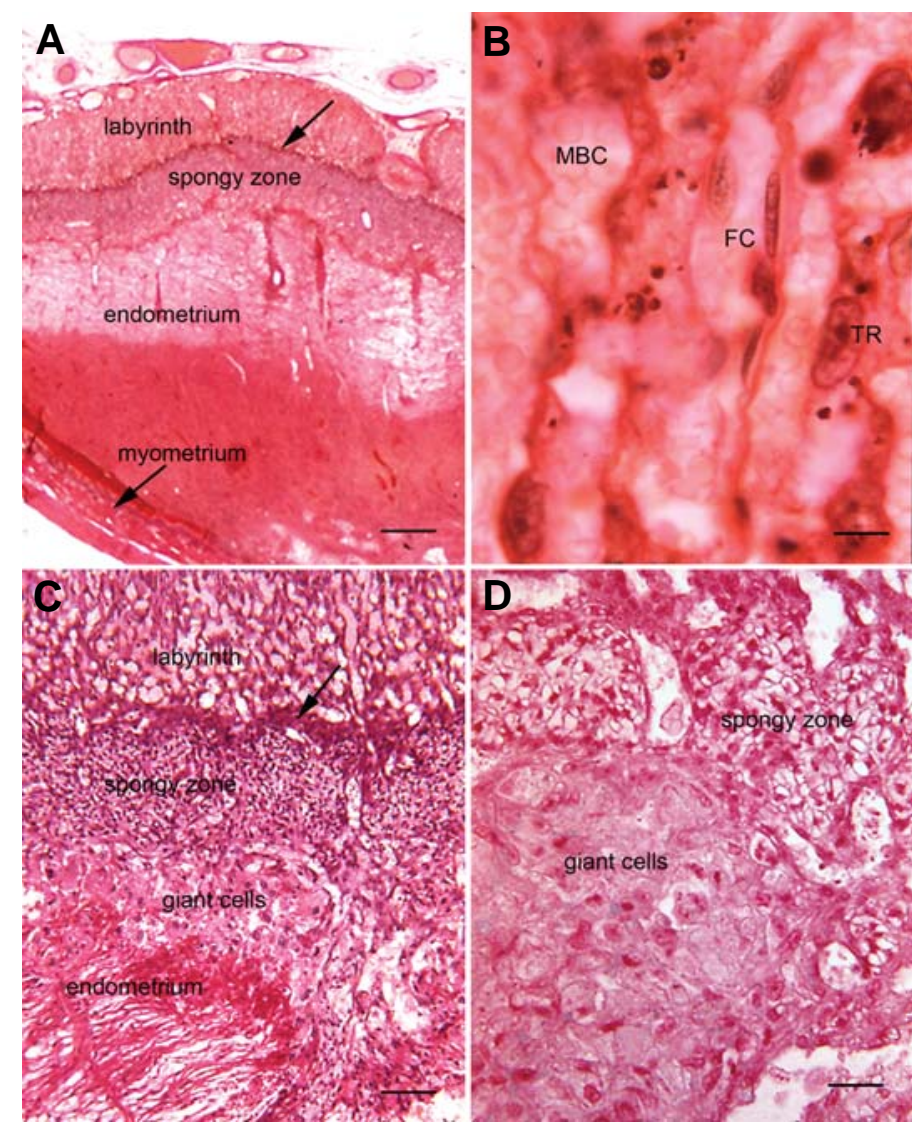


In Scalopus, too, the glandular epithelium below the areolae breaks down and the resultant debris is phagocytosed by the areolar trophoblast. In the hairy-tailed mole Parascalops breweri a striking feature is highly altered glandular cells with large nuclei indicative of polyploidy that sometimes form multinucleate masses (Enders and Carter, 2006).

\section{Placentation in hedgehogs and gymnures}

Hedgehogs (Erinaceinae) are instantly recognizable by their spiny pelage. Gymnures or moonrats (Galericinae) have coarse hair and outwardly resemble opossums. There is a growing consensus that hedgehogs and gymnures should be placed in a separate order Erinaceomorpha (Hutterer, 2005a). Because there are no recent studies of placentation in these animals, our account relies heavily on the paper by Hubrecht (1889). We have examined the original slides and, in addition, those of the South African hedgehog Atelerix frontalis found at the Harland W. Mossman Collection (Fig. 7 A-D).

Although studied only by light microscopy, there is little doubt that the hedgehog placenta is hemochorial. Even before the chorioallantoic placenta has been established, maternal blood is found in lacunae lined by trophoblast (Hubrecht, 1889). Further study is needed to tell whether the trophoblast lining the blood spaces (Fig 7B) is cellular or syncytial. There is an inner layer
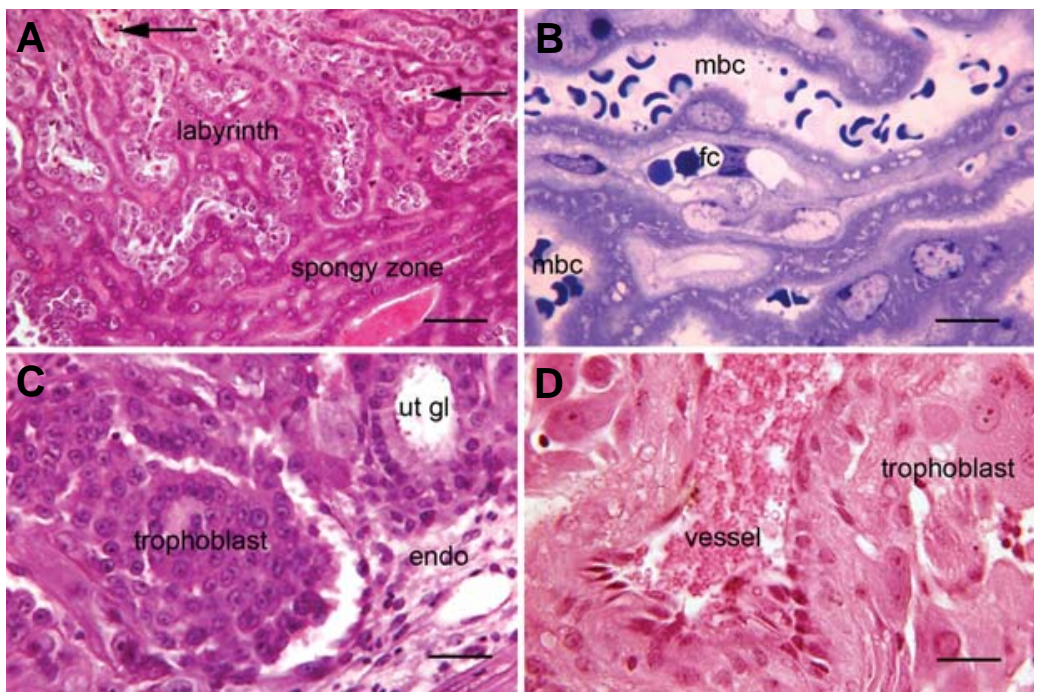

Fig. 8. Placentation in golden moles. (A) An extensive labyrinth with two layers of trophoblast melds into a spongy zone with maternal blood vessels lined by synctiotrophoblast (Eremitalpa granti). The fetal capillaries (arrows) contain nucleated erythrocytes. Courtesy of the Harland W. Mossman Collection, University of Wisconsin Zoological Museum. (B) Interhemal region of placenta of Amblysomus hottentotus in late gestation. Fetal capillaries $(f c)$ are separated from maternal blood channels by two layers of syncytiotrophoblast. (C) Multinucleate masses of trophoblast in a fetal vessel within the endometrium (endo) at the placental site. E. granti. Courtesy of the Harland W. Mossman Collection, University of Wisconsin Zoological Museum. (D) Large trophoblast cells intrude on a maternal vessel. A. hottentotus. Scale bars 88 (A), $13(B), 33(C)$ and 22 (D) $\mu \mathrm{m}$. of small basophilic cells that appears as a dark band in stained sections (Fig. 7 A,C).

A well developed spongy zone sits beneath the labyrinth and this is also present in the moonrat Echinosorex gymnura (Meister and Davis, 1953). The major cell type in this region is a highly vacuolated cell (Fig. $7 \mathrm{C}$-D). In this respect the spongy zone of hedgehogs differs from that found in hedgehog tenrecs (Carter et al., 2004) and golden moles (Gabie, 1960). Mononuclear giant cells form a distinct layer between the spongy zone and endometrium of the midgestation hedgehog placenta (Fig. 7 C-D). These cells are likely trophoblastic in origin since they are underlain by unmodified endometrial connective tissue. Hubrecht (1889) called them "deciduofracts." As a matter of fact he thought even the spongy zone was maternal in origin and coined the reciprocal terms "trophoblast" and "trophospongium" to denote what he regarded as the fetal and maternal components involved in embryonic nutrition. In Atelerix the spongy zone cells extend into maternal blood vessels. In Echinosorex mononuclear giant cells are found in clusters, some of which occupy and largely occlude maternal venous channels (Meister and Davis, 1953).

\section{Placentation in golden moles}

The golden moles are placed in the same order as the tenrecs. A revision of golden mole taxonomy is pending but currently two subfamilies are recognized (Bronner and Jenkins, 2005). Placentation has been studied in two species of Chrysochlorinae, Chrysochloris asiatica (De Lange, 1919) and Eremitalpa granti (van der Horst, 1948; Gabie, 1959, 1960) and one of Amblysominae, Amblysomus hottentotus (Jones et al., 2009).

The placental disc of the golden mole comprises a labyrinth, which makes up two-thirds of the thickness, and a spongy zone (Fig. 8A). Unlike in tenrecs there are no hemophagous regions and no secondary placenta. The interhemal area (Fig $8 \mathrm{~B}$ ) is hemodichorial with two layers of syncytiotrophoblast, the outermost being continuous with the spongy zone and in contact with the maternal blood. The inner layer, which faces the stroma and fetal blood vessels, is cellular initially but forms a syncytium in later pregnancy, and there is an interdigitating microvillous interface between the two layers. The outer trophoblast also has a microvillous apical surface facing the maternal blood.

Beneath the inner trophoblast there is a fine basal lamina and sparse stroma within which lies the fetal capillaries which are small and often difficult to detect; their basal lamina may be continuous in places with that of the inner trophoblast. In the spongy layer, there are maternal vascular spaces edged by the microvillous border of the outer syncytiotrophoblast, but the inner trophoblast and fetal stroma and capillaries do not penetrate this layer.

Masses of syncytial trophoblast occur in the maternal vessels beneath the placenta (Fig. 8C). They were originally described as endothelial in origin (van der Horst, 1948; Gabie, 1959, 1960) but we have examined some of van der Horst's slides and believe this interpretation to be erroneous. Intramural trophoblast is also observed (Fig. 8D).

\section{Placentation in tenrecs and otter shrews}

The tenrecs reached Madagascar an estimated 40 million years ago (Douady et al., 2002) and underwent an adaptive 

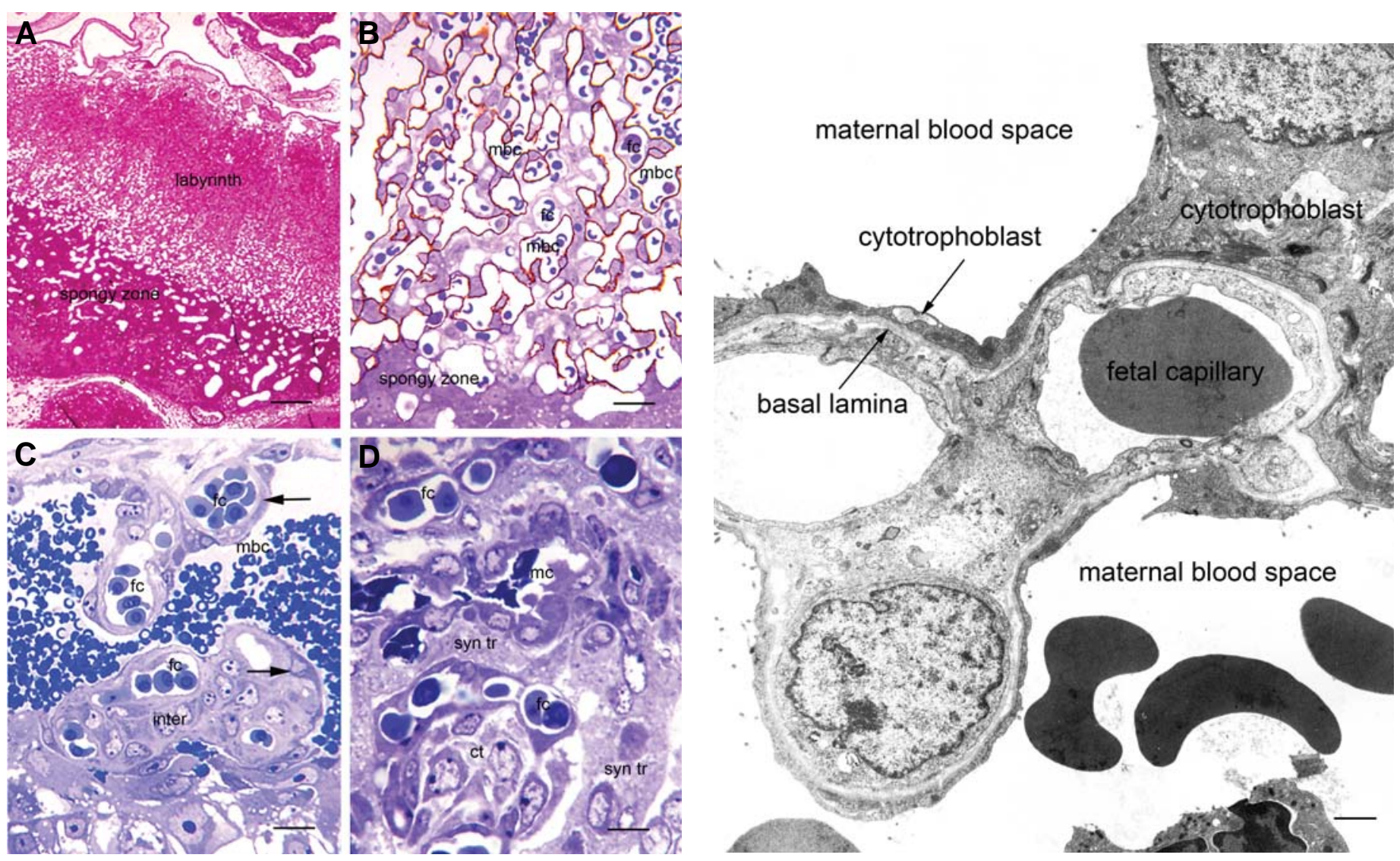

Fig. 9 (Left). Placentation in tenrecs. (A) In the lesser hedgehog tenrec (Echinops telfairi) there is a prominent spongy zone beneath the labyrinth. (B) The placenta of E. telfairi is hemochorial and the maternal blood channels ( $\mathrm{mbc}$ ) are here outlined by staining the trophoblast surface with DBA lectin. The fetal capillaries ( $f c$ ) do not stain. Courtesy of Dr. Carolyn Jones. (C) Early in gestation the placenta of the shrew tenrec (Microgale cowani) has an extensive villous region, although this later this is incorporated into the labyrinth. Fetal capillaries (fc) contain nucleated erythrocytes and are separated from the maternal blood space ( $\mathrm{mbc}$ ) by a thin layer of trophoblast (arrows). The villi also contain numbers of interstitial cells (inter). (D) The placenta of the Nimba otter shrew (Micropotamogale lamottei) is endotheliochorial. Syncytiotrophoblast (syn tr) is interposed between the fetal capillaries ( $f c$ ) and the maternal ones (mc). Some fetal connective tissue is present. Reprinted from Carter et al. (2006) copyright (C) 2006 with permission from Elsevier. Scale bars 216 (A), 22 (B), 28 (C) and 9.1 (D) $\mu \mathrm{m}$

Fig. 10 (Right). Interhemal region of the placenta in a lesser hedgehog tenrec (E. telfairi). Fetal capillaries are situated between two maternal blood spaces. The cytotrophoblast has a robust basal lamina.

radiation that resulted in three subfamilies. Placentation has been studied in the Tenrecinae and Oryzorictinae but not yet in Geogalinae. The otter shrews of mainland Africa are the closest relatives of the Malagasy tenrecs and constitute a fourth subfamily, Potamogalinae.

\section{Interhemal barrier and spongy zone}

There are excellent studies of placentation in Hemicentetes spinosus (Goetz, 1937b, 1938a, b), Setifer setosus (Strauss, 1943) and Tenrec ecaudatus (Goetz 1937a) but we shall confine our remarks on Tenrecinae to Echinops telfairi(Carter etal., 2004, 2005). The greater part of the placental disk consists of a labyrinth underlain by a spongy zone (Fig. 9A). The interhemal region (Figs. 9B, 10) is unusual in that the trophoblastic component is a single layer of cytotrophoblast. These trophoblast cells have thick areas especially near the nuclei and extensive thin flanges (Fig. 10). The luminal surface has isolated patches of microvilli, and pinocytotic vesicles are numerous both apically and basally. The labyrinthine zone ends abruptly at the margins of the placental disk. However, the endoderm and connective tissue of the allantois and a layer of cytotrophoblast extend beyond the placental disk as a paraplacental region.

Placentation in Microgaleand two other genera of the subfamily Oryzorictinae is different from that in Tenrecinae (Enders et al., 2007). Developmentally a more villous portion of the placental disk forms before the formation of a compact labyrinth (Fig. 9C). Although the definitive placenta is cellular hemomonochorial, it lacks the spongy zone found in the Tenrecinae.

The Nimba otter shrew Micropotamogale lamottei has an endotheliochorial labyrinth with syncytial trophoblast enclosing the maternal vessels (Fig. 9D). There is no spongy zone (Carter et al., 2006). The placenta of the giant otter shrew Potamogale velox is also endotheliochorial (Carter et al., 2006).

\section{Histotrophic nutrition}

Areolae have been observed in the paraplacental region of 
Tenrec ecaudatus (Goetz, 1937a), but the hedgehog tenrecs are better known for their prominent hemophagous regions. In Echinops telfairi this develops early from polarized trophoblast (Fig 11A) overlying the glands at the centre of the implantation site (Carter et al., 2005). Later the trophoblast becomes highly folded to form a prominent organ at the centre of the placental disc. The primary folds have allantoic endoderm at one surface and columnar cytotrophoblast at the other. These trophoblast cells have numerous lipid droplets and vesicles, and often contain large yellow pigment crystalloids (Fig 11B). There is scant evidence of phagocytosis in later stages of pregnancy, but the crystals of hematoidin impart a yellow hue to the entire structure (Carter et al., 2004). In Oryzorictinae there is an early, simple and lateral rather than central hemophagous region. In the otter shrews, however, there is again a prominent hemophagous region (Enders et al., 2007). In Potamogale velox, the central region (Fig. 11C) at first sight appears to be a placental disk (Hill, 1938), yet the juxtafetal portion is clearly a hemophagous region whereas the labyrinth leading to this region is endotheliochorial (Carter et al., 2006).

\section{Implications for systematics}

The history of insectivore systematics is admirably reviewed by Symonds (2005). The most recent developments have been removal of tenrecs and golden moles to a separate order Afrosoricida and partition of the remainder between Erinaceomorpha (hedgehogs and gymnures) and Soricomorpha (shrews, moles and solenodons).

There is some support for the Erinaceomorpha-Soricomorpha split from differences in early development and placentation (Table 1). In hedgehogs implantation is interstitial, amniogenesis occurs by cavitation, the interhemal barrier is hemochorial and there is a prominent spongy zone. In shrews and moles implantation is superficial, amniogenesis is by folding, the interhemal barrier is endotheliochorial and a spongy zone is absent. As in analyses of other morphological characters (Asher, 2001), Solenodon with its hemochorial placenta does not quite fit.

It is difficult to form a coherent picture of placentation in Afrosoricida (Table 2). There are striking differences even between the subfamilies of tenrecs with the interhemal barrier being endotheliochorial in otter shrews and hemochorial in Tenrecinae and Oryzorictinae. One feature of Afrosoricida that has been highlighted is division of the allantoic sac into four lobes in Potamogaleand Chrysochloris. This is widely accepted as a synapomorphy for Afrotheria (Mess and Carter, 2006, Seiffert, 2007; Asher and Lehmann, 2008). It could equally be the result of homoplasy as has occurred in the evo- lution of other characters in mammals (Luo, 2007).

Debate on the systematics of insectivoran grade mammals is far from over. In a recent paper, Wible et al. (2007) challenged the monophyly of superorders Laurasiatheria and Afrotheria since in their analysis Potamogale nested within laurasiatherian insectivores. As Symonds (2005) remarked, with reference to Simpson's (1945) famous pronouncement on Lipotyphla, "The wastebasket may have been emptied, but its contents are currently strewn over the floor." A major challenge in mammalian systematics remains the integration of molecular and morphological data for living and fossil forms (Springer et al., 2004).

\section{What needs to be done?}

The wealth of data offered by comparative genomics cannot be exploited without data on the phenotype. Functional studies should focus on the three insectivoran grade mammals selected for whole genome sequencing. As described above, our knowledge of placentation in the tenrec Echinops telfairi is fairly complete although it would be nice to have details of events up to and including blastocyst implantation. Sorex araneus was the shrew studied by Hubrecht (1894) and there is more recent data on $S$. fumeus (Wimsatt and Wislocki, 1947; Wislocki and Wimsatt, 1947). Our first priority therefore must be to apply modern techniques to the hedgehog Erinaceus europaeus as there have been no substantial studies of the genus since Hubrecht (1889). Because Erinaceus would need to be trapped in the wild, it might be more feasible to study the African genus Atelerix which is available from breeders.

In the context of comparative placentation the formation and nature of the interhemal barrier in moles needs to be revisited. Work is underway on a member of the Talpinae, Talpa occidentalis (Siniza and Zeller, 2007). However, the real bone of contention is
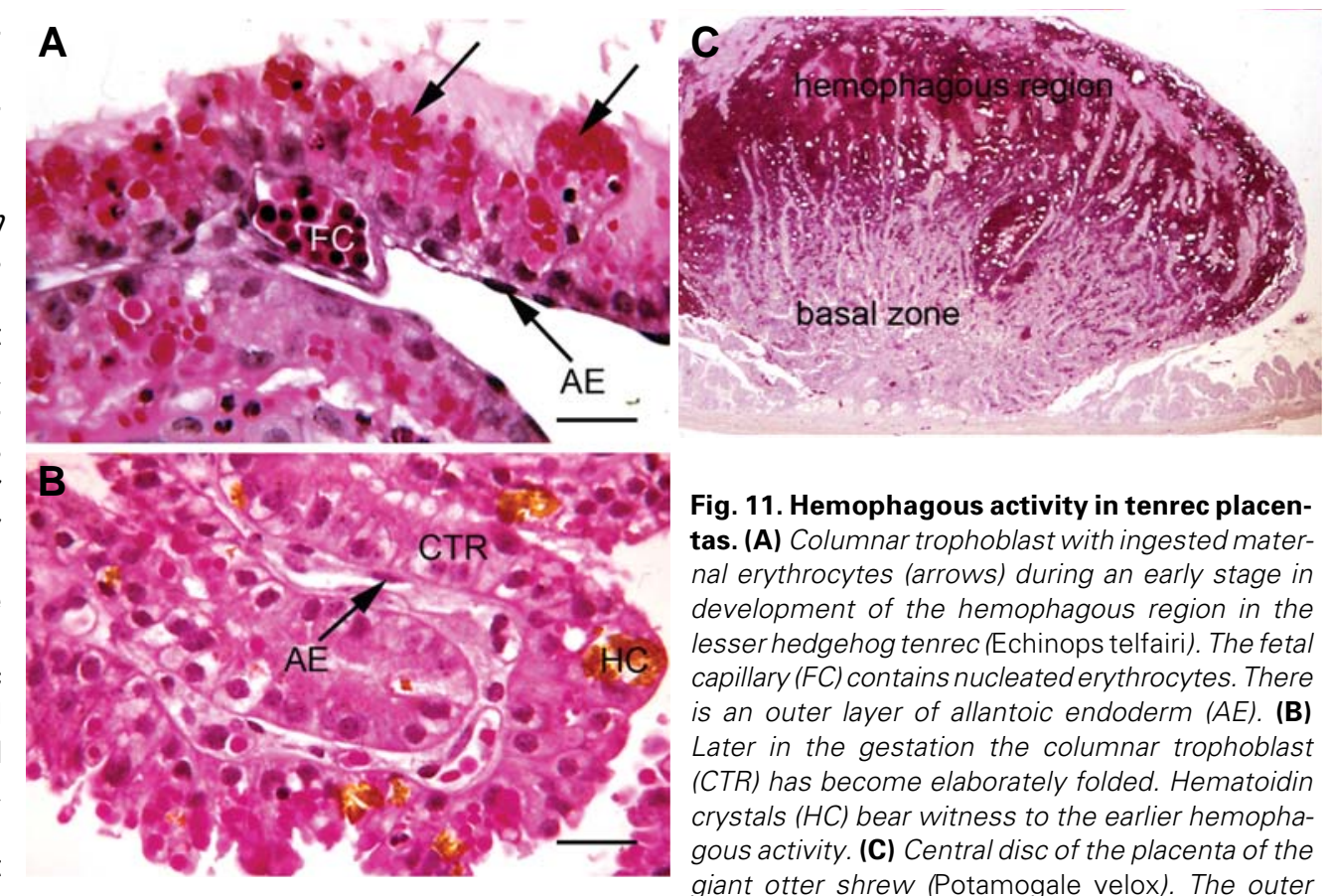

Fig. 11. Hemophagous activity in tenrec placentas. (A) Columnar trophoblast with ingested maternal erythrocytes (arrows) during an early stage in development of the hemophagous region in the lesser hedgehog tenrec (Echinops telfairi). The fetal capillary (FC) contains nucleated erythrocytes. There is an outer layer of allantoic endoderm (AE). (B) Later in the gestation the columnar trophoblast (CTR) has become elaborately folded. Hematoidin crystals (HC) bear witness to the earlier hemophagous activity. (C) Central disc of the placenta of the giant otter shrew (Potamogale velox). The outer zone forms the hemophagous region whilst the basal zone is part of the exchange area. Reprinted from Carter et al. (2006) (C) 2006 with permission from Elsevier. Scale bars 22 (A-B), 218 (C) $\mu \mathrm{m}$. 
whether members of Scalopinae have epitheliochorial placentation. At present the evidence for this rests on the interpretation of a single specimen by Prasad et al. (1979). What is needed is a developmental series of Scalopus or Scapanus. An intriguing feature of placentation in Suncus murinus is the presence of large numbers of invasive binucleate trophoblast cells (Sansom, 1937). The origin and fate of these cells begs renewed study. Thirdly it would be instructive to study placentation in golden moles at the ultrastructural level.

Whenever new studies are planned it is important to put tissues aside for later genomic research. Tissue reagents are available that stabilize RNA (Wildman, 2008). A bank of placental tissue could prove a resource equal in value to the embryological collections that have been conserved by earlier generations of researchers (Carter, 2008).

Finally we confess to curiosity about placentas that have never before been studied. Would Geogale offer yet a fourth variant on tenrec placentation? Does Myosorex, in many ways intermediate between soricine and crocidurine shrews, sport a trophoblastic sheath? What surprises await us in the placentas of gymnures and Asiatic shrew-moles?

\section{Acknowledgements}

It is a pleasure to acknowledge Paula Holahan for making material available from the Harland W. Mossman Collection at the University of Wisconsin Zoological Museum. We thank Jenny Narraway and Peter Giere for access to the Hubrecht and Hill Collections, which are presently located at Museum für Naturkunde Berlin. Material for our published and unpublished studies was generously supplied by Nigel Bennett (Amblysomus), Steven Goodman (Microgale), Heinz Künzle (Echinops), and Peter Vogel (Micropotamogale). The studies were supported in part by The Carlsberg Foundation, Denmark (AMC).

\section{References}

ASHER, R.J. (2001). Cranial anatomy in tenrecid insectivorans: Character evolution across competing phylogenies. Novitates 3352: 1-54.

ASHER, R.J. and LEHMANN, T. (2008). Dental eruption in afrotherian mammals. BMC Biology 6: 14.

BEDFORD, J.M., MOCK, O.B. and GOODMAN, S.M. (2004). Novelties of conception in insectivorous mammals (Lipotyphla), particularly shrews. Biol Rev Camb Philos Soc 79: 891-909.

BRAMBELL, F.W.R. and PERRY, J.S. (1945). The development of the embryonic membrane of the shrews, Sorex araneus Linn. and Sorex minutus Linn. Proc Zool Soc London 115: 251-276.

BRONNER, G.N. and JENKINS, P.D. (2005). Order Afrosoricida. In Mammal Species of the World. A Geographic and Taxonomic Reference. (Eds. Wilson, D.E. and Reeder, D.M.) The Johns Hopkins University Press, Baltimore, pp. 7181.

CARTER, A.M. (2005). Classics revisited. Placentation in an American mole, Scalopus aquaticus. Placenta 26: 597-600.

CARTER, A.M. (2008). Sources for comparative studies of placentation. I. Embryological collections. Placenta 29: 95-98.

CARTER, A.M., BLANKENSHIP, T.N., KÜNZLE, H. and ENDERS, A.C. (2004). Structure of the definitive placenta of the tenrec, Echinops telfairi. Placenta25: 218-232.

CARTER, A.M., BLANKENSHIP, T.N., KÜNZLE, H. and ENDERS, A.C. (2005). Development of the haemophagous region and labyrinth of the placenta of the tenrec, Echinops telfairi. Placenta 26: 251-261.

CARTER, A.M., BLANKENSHIP, T.N., ENDERS, A.C. and VOGEL, P. (2006). The fetal membranes of the otter shrews and a synapomorphy for Afrotheria. Placenta 27: 258-268.
DE LANGE, D. (1919). Contribution to knowledge of the placentation of the Cape golden mole (Chrysochloris). Bijd Dierkunde Amsterdam 21: 161-173.

DOUADY, C.J., CATZEFLIS, F., KAO, D.J., SPRINGER, M.S. and STANHOPE, M.J. (2002). Molecular evidence for the monophyly of Tenrecidae (Mammalia) and the timing of the colonization of Madagascar by Malagasy Tenrecs. Mol Phylogenet Evol22: 357-363.

ENDERS, A.C., BLANKENSHIP, T.N., GOODMAN, S.M., SOARIMALALA, V. and CARTER, A.M. (2007). Placental diversity in Malagasy tenrecs: placentation in shrew tenrecs (Microgalespp.), the mole-like rice tenrec (Oryzorictes hova) and the web-footed tenrec (Limnogale mergulus). Placenta 28: 748-59.

ENDERS, A.C. and CARTER, A.M. (2006). Comparative placentation: some interesting modifications for histotrophic nutrition - a review. Placenta 27 Suppl A: S11-S16.

GABIE, V. (1959). The early embryology of Eremitalpa granti (Broom). J Morphol 104: $181-204$.

GABIE, V. (1960). The placentation of Eremitalpa granti(Broom). J Morpho/107: 61-78.

GOETZ, R.H. (1937a). Studien zur Placentation der Centetiden. I. Eine Neuuntersuchung der Centetesplacenta. Z Anat Entwick/106: 315-342.

GOETZ, R.H. (1937b).Studien zur Placentation der Centetiden. II. Die Implantation und Frühentwicklung von Hemicentetes semispinosus (Cuvier). ZAnat Entwickl 107: $274-318$

GOETZ, R.H. (1938a). On the early development of the Tenrecoidea (Hemicentetes spinosus). Biomorphosis 1: 67-79.

GOETZ, R.H. (1938b). Studien zur Placentation der Centetiden. III. Die Entwicklung der Fruchthüllen und der Placenta bei Hemicentetes semispinosus (Cuvier). $Z$ Anat Entwick/108: 161-200.

HILL, J.P. (1938). The macroscopic features of the placenta of the water shrew (Potamogale velox). Biomorphosis 1: 331-332.

HUBRECHT, A.A.W. (1889). The Placentation of Erinaceus europaeus with remarks on the phylogeny of the placenta. Quart J Microscop Sci30: 283-404.

HUBRECHT, A.A.W. (1894). The placentation of the shrew (Sorex vulgaris, L.). Quart J Microscop Sci35: 481-537.

HUBRECHT, A.A.W. (1898). La formation de la decidua reflexa chez les genres Erinaceus et Gymnura. Annales du Jardin Botanique du Buitenzorg Suppl. 2: 159-167.

HUTTERER, R. (2005a). Order Erinaceomorpha. In Mammal Species of the World. A Geographic and Taxonomic Reference. (Eds. Wilson, D.E. and Reeder, D.M.) The Johns Hopkins University Press, Baltimore, pp. 212-219.

HUTTERER, R. (2005b). Order Soricomorpha In Mammal Species of the World. A Geographic and Taxonomic Reference. (Eds. Wilson, D.E. and Reeder, D.M.) The Johns Hopkins University Press, Baltimore, pp. 220-311.

JI, Q., LUO, Z.X., YUAN, C.X., WIBLE, J.R., ZHANG, J.P. and GEORGI, J.A. (2002). The earliest known eutherian mammal. Nature 416: 816-822.

JONES, C.J.P., CARTER, A.M., BENNETT, N.C., BLANKENSHIP, T.N. and ENDERS, A.C. (2009).Placentation in the Hottentot Golden Mole. Placenta 30: 571-578.

KIELAN-JAWOROWSKA, Z., CIFELLI, R.L. and LUO, Z.X. (2004). Mammals from the Age of Dinosaurs. Origins, Evolution, and Structure. Columbia University Press, New York.

KING, B.F., ENDERS, A.C. and WIMSATT, W.A. (1978).The annular hematoma of the shrew yolk-sac placenta. Am J Anat 152: 45-57.

KISO, Y., YASUFUKU, K., MATSUDA, H. and YAMAUCHI, S. (1990). Existence of an endothelio-endothelial placenta in the insectivore, Suncus murinus. Cell Tissue Res 262: 195-197.

LUO, Z.X. (2007). Transformation and diversification in early mammal evolution. Nature 450: 1011-1019.

LUO, Z.X., JI, Q., WIBLE, J.R. and YUAN, C.X. (2003). An Early Cretaceous tribosphenic mammal and metatherian evolution. Science 302: 1934-1940.

MALASSINE, A. and LEISER, R. (1984). Morphogenesis and fine structure of the near-term placenta of Talpa europaea: I. Endotheliochorial labyrinth. Placenta 5: $145-158$.

MEISTER, W. and DAVIS, D.D. (1953). Placentation of a primitive insectivore, Echinosorex gymnura. Fieldiana: Zoo/35: 11-26. 
MESS, A., CARTER, A.M. (2006). Evolutionary transformations of fetal membrane characters in Eutheria with special reference to Afrotheria. J Exp Zoolog B Mol Dev Evo/306: 140-163.

MIGLINO, M.A., CARTER, A.M., DOS SANTOS FERRAZ, R.H., FERNANDES MACHADO, M.R. (2002). Placentation in the capybara (Hydrochaerus hydrochaeris), Agouti (Dasyprocta aguti) and paca (Agoutipaca). Placenta23: 416-428.

MORRIS, B. (1958). The yolk-sac of the mole Talpa europea. Proc Zool Soc Lond 131: $367-387$.

MOSSMAN, H.W. (1939). The epitheliochorial placenta of an American mole, Scalopus aquaticus. Proc Zool Soc Lond B 109: 373-375.

MOSSMAN, H.W. (1987). Vertebrate Fetal Membranes: Comparative Ontogeny and Morphology; Evolution; Phylogenetic Significance; Basic Functions; Research Opportunities. The Macmillan Press Ltd., Houndmills, Basingstoke, Hampshire and London.

MURPHY, W.J., EIZIRIK, E., O'BRIEN, S.J., MADSEN, O., SCALLY, M., DOUADY, C.J., TEELING, E., RYDER, O.A., STANHOPE, M.J., DE JONG, W.W. and SPRINGER, M.S. (2001). Resolution of the early placental mammal radiation using Bayesian phylogenetics. Science 294: 2348-2351.

OWERS, N.O. (1960). The endothelio-endothelial placenta of the Indian musk shrew, Suncus murinus-a new interpretation. Am J Anat 106: 1-25.

PRASAD, M.R.N. (1958) Morphogenesis of the fetal membranes of the American moles Scalopus aquaticus, Scapanus latimanus and Parascalops breweri. Ph.D. Thesis, University of Wisconsin.

PRASAD, M.R., MOSSMAN, H.W. and SCOTT, G.L. (1979). Morphogenesis of the fetal membranes of an American mole, Scalopus aquaticus. Am JAnat 155: 31 68.

SANSOM, G.S. (1937). The placentation of the Indian musk-shrew (Crocidura caerulea). Trans Zool Soc London 23: 267-314.

SEIFFERT, E.R. (2007). A new estimate of afrotherian phylogeny based on simultaneous analysis of genomic, morphological, and fossil evidence. BMC Evol Biol7: 224

SIMPSON, G.G. (1945). The principles of classification and a classification of mammals. Bull Am Mus Nat Hist 85: 1-350.

SINIZA, S. and ZELLER, U. (2007). The morphology and ultrastructure of the placenta of the Iberian Mole (Talpa occidentalis) (abstract). J Morpho/ 268: 1135 .
SPRINGER, M.S. and MURPHY, W.J. (2007). Mammalian evolution and biomedicine: new views from phylogeny. Biol Rev Camb Philos Soc 82: 375-392.

SPRINGER, M.S., STANHOPE, M.J., MADSEN, O. and DE JONG, W.W. (2004) Molecules consolidate the placental mammal tree. Trends Ecol Evol19: 430438.

STANHOPE, M.J., WADDELL, V.G., MADSEN, O., DE JONG, W., HEDGES, S.B. CLEVEN, G.C., KAO, D. and SPRINGER, M.S. (1998). Molecular evidence for multiple origins of Insectivora and for a new order of endemic African insectivore mammals. Proc Natl Acad Sci USA 95: 9967-9972.

STARCK, D. (1959).Ontogenie und Entwicklungsphysiologie der Säugetiere. In Handbuch der Zoologie, volume 8, part 22, 9 (7) (Ed. Kükenthal, W.) Walter Gruyter Berlin, pp. 1-276.

STRAHL, H. (1892).Untersuchungen über den Bau der Plazenta. V. Die Placenta von Talpa europaea. Anat Hefte 1: 113-161.

STRAUSS, F. (1943). Die Placentation von Ericulus setosus. Rev Suisse Zoo/50: 17-87.

SYMONDS, M.R. (2005). Phylogeny and life histories of the "Insectivora": controversies and consequences. Biol Rev Camb Philos Soc 80: 93-128.

VAN DER HORST, C.J. (1948). Some early embryological stages of the golden mole Eremitalpa granti (Broom). Special Publication of the Royal Society of South Africa - Robert Broom Commemmorative Volume, pp 225-234.

WIBLE, J.R., ROUGIER, G.W., NOVACEK, M.J. and ASHER, R.J. (2007). Cretaceous eutherians and Laurasian origin for placental mammals near the $\mathrm{K} / \mathrm{T}$ boundary. Nature 447: 1003-1006.

WILDMAN, D.E. (2008). Sources for comparative studies of placentation. II. Genomic resources. Placenta 29: 144-147.

WIMSATT, W.A., ENDERS, A.C. and MOSSMAN, H.W. (1973). A reexamination of the chorioallantoic placental membrane of a shrew, Blarina brevicauda: resolution of a controversy. Am J Anat 138: 207-233.

WIMSATT, W.A. and WISLOCKI, G.B. (1947). The placentation of the American shrews, Blarina brevicaudata and Sorex fumeus. Am J Anat 80: 361-435.

WISLOCKI, G.B. (1940).The placentation of Solenodon paradoxus. Am J Anat66: 497-531.

WISLOCKI, G.B. and WIMSATT, W.A. (1947). Chemical cytology of the placenta of two North American shrews (Blarina brevicaudata and Sorex fumeus). Am J Anat 81: 269-308. 


\section{Further Related Reading, published previously in the Int. J. Dev. Biol.}

See our recent Special Issue Epigenetics \& Development edited by Saadi Khochbin and Stefan Nonchev at:

http://www.ijdb.ehu.es/web/contents.php?vol=53\&issue=2-3

See Special Issue Pattern Formation edited by Michael K. Richardson and Cheng-Ming Chuong at:

http://www.ijdb.ehu.es/web/contents. php?vol=53\&issue=5-6

The spatio-temporal pattern of testis organogenesis in mammals - insights from the mole

Francisco D. Carmona, Darío G. Lupiáñez, José-Ezequiel Martín, Miguel Burgos, Rafael Jiménez and Federico Zurita

Int. J. Dev. Biol. (2009) 53: 1035-1044

Regulation of sperm storage and movement in the mammalian oviduct

Susan S. Suarez

Int. J. Dev. Biol. (2008) 52: 455-462

Spatiotemporal expression of the selenoprotein $\mathbf{P}$ genein postimplantational mouse embryos

Se-Ra Lee, Jung-Min Yon, In-Jeoung Baek, Mi-Ra Kim, Chun-Gui Park, Beom-Jun Lee, Young-Won Yun and Sang-Yoon Nam Int. J. Dev. Biol. (2008) 52: 1005-1011

Puzzles of mammalian fertilization - and beyond

J. Michael Bedford

Int. J. Dev. Biol. (2008) 52: 415-426

An activating mutation in the PDGF receptor-beta causes abnormal morphology in the mouse placenta

Camilla Looman, Tong Sun, Yang Yu, Agata Zieba, Aive Ahgren, Ricardo Feinstein, Henrik Forsberg, Carina Hellberg, Carl-Henrik Heldin, Xiao-Qun Zhang, Karin Forsberg-Nilsson, Nelson Khoo, Reinald Fundele and Rainer Heuchel

Int. J. Dev. Biol. (2007) 51: 361-370

A simple in vivo approach to investigate invasive trophoblast cells Juan A. Arroyo, Toshihiro Konno, Darya C. Khalili and Michael J. Soares Int. J. Dev. Biol. (2005) 49: 977-980

Control of reproduction by Polycomb Group complexes in animals and plants Anne-Elisabeth Guitton and Frederic Berger Int. J. Dev. Biol. (2005) 49: 707-716

Commitment of hematopoietic stem cells in avian and mammalian embryos: an ongoing story

Françoise Dieterlen-Lièvre

Int. J. Dev. Biol. (2005) 49: 125-130

The place of phylogeny and cladistics in Evo-Devo research.

Maximilian J Telford and Graham E Budd

Int. J. Dev. Biol. (2003) 47: 479-490

Developmental genetics in Sheffield: a meeting point for Hedgehog researchers. $M$ Placzek and $\mathrm{P}$ W Ingham Int. J. Dev. Biol. (2000) 44: 65-72

Changes in the placenta and in the rat embryo caused by the demethylating agent 5azacytidine.

M Vlahovic, F Bulic-Jakus, G Juric-Lekic, A Fucic, S Maric and D Serman Int. J. Dev. Biol. (1999) 43: 843-846

Transgenic mice ubiquitously expressing human placental alkaline phosphatase (PLAP): an additional reporter gene for use in tandem with beta-galactosidase (lacZ). M J Skynner, D J Drage, W L Dean, S Turner, D J Watt and N D Allen Int. J. Dev. Biol. (1999) 43: 85-90

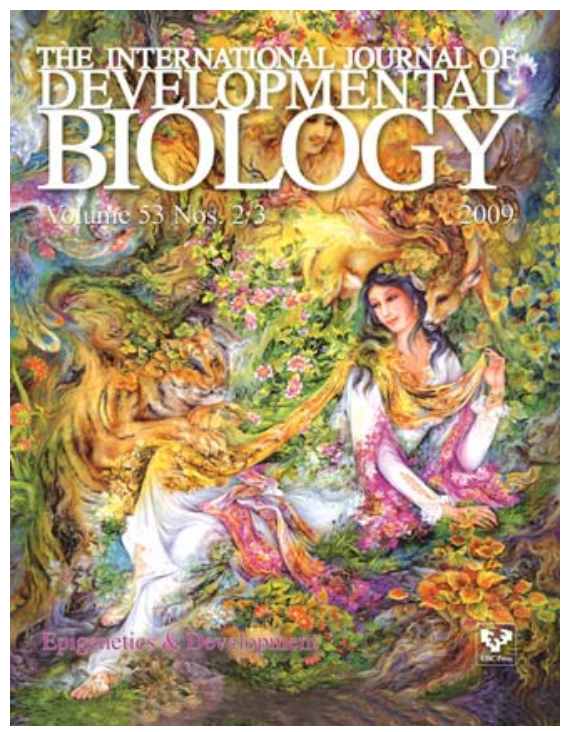

5 yr ISI Impact Factor $(2008)=3.271$



